\title{
Anisakidae as a Bioindicator Candidate in Response to Environmental Damage
}

\author{
$1^{\text {st }}$ Hartanto M. Raharjo \\ dept. of Veterinary Science \\ Faculty of Vet. Medicine, Airlangga University \\ Surabaya, Indonesia \\ hartantomulyoraharjo@gmail.com \\ $2^{\text {nd }}$ Setiawan Koesdarto \\ dept. of Veterinary Parasitology \\ Faculty of Vet. Medicine, Airlangga University \\ Surabaya, Indonesia \\ $3^{\text {rd }}$ Qabilah C. K. N. Sumarsono, Febrina D. Permatasari, Zafitri N. Wastomi, Nurul S. A. Sari \\ dept. Science of Disease and Veterinary Public Health \\ Faculty of Vet. Medicine, Airlangga University \\ Surabaya, Indonesia
}

\begin{abstract}
The increase of environmental damage in coastal and marine areas can affect the presence of marine ecosystems and fishery products such as reducing the type of fish, and causing the decline of fish obtained from the sea. This will certainly affect the socio-economy in coastal areas, especially for groups of fishermen and traders. To prevent the occurrence of environmental damage in coastal and marine areas, it is necessary to develop an early warning system. Anisakidae has the potential as an early warning system as it works as a bioindicator. This research was expost facto research with purposive sampling from two different areas in East Java, between January and March 2016. Thirty samples of groupers from coastal Probolinggo were the areas exposed to anthropogenic effects and thirty samples from coastal Tuban were selected as areas far from anthropogenic effects. The results showed that Anisakidae in groupers between the sample from coastal Probolinggo and coastal Tuban had different levels of parasitological indexes. The prevalence from coastal Probolinggo was only $10 \%$, with the infestation rate being very low 2 . It was different with the sample from coastal Tuban, with the prevalence being $80 \%$ and infestation rate $5.9 \%$. The data was analysed with a Mann Whitney test which showed that there was a significant difference in Anisakidae infestation in groupers between the two areas. This research showed that areas exposed to anthropoghenic effects have a low infestation rate of Anisakidae if compared with areas far from anthropogenic effects. Knowing the infestation rate of Anisakidae, people and the government can measure and overcome environmental damage in coastal and marine areas.
\end{abstract}

\section{Keywords-Anisakidae; Infestation rate; Bioindicator;} Environmental damage

\section{INTRODUCTION}

Ecosystems along the coastal zone are the most vulnerable natural systems on the surface of the earth, and face increasing anthropogenic stress in terms of pollution and environmental damage. Approximately 2.75 billion people are expected to live per 60 miles of coastline by 2025, living directly or indirectly using coastal environments. This region is the centre of the highest water biodiversity, especially in tropical coastal waters. It is clear that anthropogenic activity directly affects the species composition and biodiversity of the water, negatively affecting the long-term sustainability of the ecosystem. The biodiversity of the parasites in fish and its species composition depends on the species richness of the final host and its ecosystem.

Fish fauna globally comprises more than 31,400 species, and about half of them (14,970 species) live at sea. Due to the long-term stability of marine ecosystems, the diversity of marine fish parasites per host is higher than that of freshwater fish. From 30,000 known fish species, there is estimated to be around 100,000 fish parasites inside, thus obtaining an average of 3.3 species of parasites in each fish [1]. Canadian water recorded 925 different fish parasites in 292 marine and freshwater fish, including protozoa and metazoa (3.2 species of parasites / fish species) [2][3]. Germany reported 191 different metazoan parasite species from northern German coastal waters, as many as 62 species of wild fish from the North coast and the Baltic Sea stored an average of 3.1 species of metazoan parasites per fish species [4]. This is in contrast to the deep ocean, where the average number of parasites per fish species 
is 1.5, a value that has not increased in the last 8 years [5][6]. On the basis of the existence of more than three species of fish parasites in each species of fish, it can be estimated that there are 120,000 species of fish parasites, including protozoa and metazoa.

The water environment can be studied directly by the routine monitoring of water quality parameters or indirectly using bioindicators [7], such as fish parasites [8]. These organisms react to certain environmental conditions or changes, leading to various applications such as the bioindication for water quality [9], environmental stress [10], and pollution [11][12]. Fish parasites can be used to detect environmental impacts that have occurred, and to distinguish between accumulated or affected bioindicators, in which the organism takes the waste substance [13]. This is done to record definite changes in their physiology, chemical composition, behaviour or numbers. Other parasitic metrics such as diversity index or species richness may be a source of information [14], or show the possible effects of environmental conditions on fish parasites [15][16][17][18][19].

Based on the description above, this research intends to know the prevalence and infestation rate of Anisakidae in groupers (Epinephelus coioides) in areas exposed to anthropogenic effects and areas far from anthropogenic effects to analyse the proper function of Anisakidae as a bioindicator candidate in response to environmental damage.

\section{MATERIALS AND METHODS}

This research was a research study with purposive sampling from two different areas in East Java. Between January and March 2016, thirty sample of groupers (Epinephelus coioides) of a total length (tl) of $27-30 \mathrm{~cm}$ and weight of 300-400 grams from coastal Probolinggo as areas exposed to anthropogenic effects and thirty samples with the same criteria from coastal Tuban as areas far from anthropogenic effects were investigated for the presence of anisakid nematodes. Specimens from coastal Tuban were purchased from Palang Fish Auction (6 $6^{\circ} 54^{\prime} 8^{\prime \prime} \mathrm{S}$ and $112^{\circ} 8,34^{\prime \prime}$ E) and specimens from coastal Probolinggo were purchased from Sedati Fish Auction ( $7^{\circ} 23^{\prime} 18^{\prime \prime} \mathrm{S}$ and $112^{\circ}$ $48^{\prime} 28^{\prime}$ ' E). The fish were conserved in an insulated box with ice, and were then transferred to the Laboratory of Veterinary Parasitology, in the Faculty of Veterinary Medicine, Airlangga University. The specimens were identified and were then necropsied and filleted. Nematode larvae were observed with microscope and were recovered in Petri dishes in a $0.65 \% \mathrm{NaCl}$ solution. Parasitological index prevalence was calculated from the number of hosts infested divided by the number of hosts examined, and for the infestation rate, the total number parasites found in the sample was divided by the number of hosts infested [20]. The comparison of Anisakidae infestation in groupers between two areas analysed by Mann Whitney test used IBM SPSS Statistics 22.

\section{RESULTS AND DISCUSSION}

The research results showed that there is difference in prevalence and infestation rate between groupers (Epinephelus coioides) from coastal Probolinggo and coastal Tuban.

TABLE I. PARASITOLOGICAL INDEX OF ANISAKIDAE

\begin{tabular}{|l|l|c|c|}
\hline No & \multicolumn{1}{|c|}{ Area } & P $(\%)$ & IR \\
\hline 1. & Coastal Probolinggo & 10 & $2 \pm 30$ \\
\hline 2. & Coastal Tuban & 80 & $5.9 \pm 30$ \\
\hline
\end{tabular}

Table I. shows the prevalence of Anisakidae in coastal Probolinggo with only a $10 \%$ with an infestation rate of $2 \pm 30$, and coastal Tuban had a prevalence of $80 \%$ with an infestation rate of $5.9 \pm 30$. Mann Whitney test showed the significantly different between two areas.

In marine coastal areas, human activities directly influence living communities, which may result in a heavier parasite infestation compared to less polluted sites [21]. On the other hand, some parasite species can disappear and thus reduce parasite diversity within the system. While it remains difficult to find the best host, a parasite system can indicate a specific parameter change. This brought in the idea to use fish parasites as an early warning system for pollution and environmental change [22]. The Tuban coast is a part of the south-eastern Java Sea, and is more stable from anthropogenic effects if we compare it with the Probolinggo coastal which is part of the Madura Strait, the estuary of the Brantas River in East Java. As the river goes through big cities like Surabaya and Sidoarjo, this river transfers a very high anthropogenic influence to the Madura Strait. Not only that, since May 2006, the Indonesian mud volcano, Lumpur Lapindo provides a unique example of how geohazards in a tectonically active region can add to the impact of human activities in a river catchment to do with sediment, carbon input and the ecology of the downstream aquatic environment. In contrast to most of the natural disasters which lead to short-term pulses of water and sediment input, the Indonesian mud volcano has been a continuous source of sediment and carbon in to the aquatic environment. As no end of the mud emanation is in sight, the observed carbon and ammonium input and resultant oxygen depletion will probably become a quasi-permanent feature with long-term deleterious effects on water quality, the ecology of the Porong River estuary, and adjacent coastal waters around Madura Strait. The effect of these extreme events has to be taken into account for the management of coastal zones [23].

The damage and changes in the environment can indirectly affect marine mammals as a definitive host of Anisakidae, as their migration pattern becomes the spreading source of the parasitic worms to other marine animals [24][25]. In June 2016, thirty two pilot whales (Globicephala macrorhynchus) became stranded on the coast of Probolinggo. Pilot whales are known to be the main host of Anisakidae. With this fact in mind, there is possibility that something disturb the life cycle of Anisakidae [26]. 
The presence of parasites within the environment often becomes evident after a massive infestation causing clinical signs or leading to the mortality of the infected hosts. Such a situation can be combined with biotic or abiotic changes in the environment [27], in the application of fish parasites as environmental indicators. Knowledge of the biology of the parasite and its host, the host-parasite relationship and the environment can help to detect environmental changes. Anisakidae life cycle stages provide information on the migration of their hosts and also about the changes in their abundance in the host if some of their life cycle stages become affected through the disappearance of their intermediate hosts, provoking disappearance of some parasite species under polluted conditions.

\section{CONCLUSION}

A proper selection of the parasites utilised and their specific life cycle stages is a prerequisite for bioindicator applications. Anisakidae has a high chance of becoming a bioindicator in the future. As a bioindicator candidate, Anisakidae can elucidate problems in a variety of applications. They can be used to measure the impact of environmental damage and they can be useful to determine and measure marine resource abundance in aquatic ecosystems. By knowing the infestation rate of Anisakidae, people and the government can measure and overcome the environmental damage effect in coastal and marine areas.

Further research is need to make Anisakidae become proper bioindicator.

\section{Acknowledgment}

The present study was supported by the Anisakis Research Team and the Department of Veterinary Parasitology, in the Faculty of Veterinary Medicine of Airlangga University. Thanks to all for the contribution.

\section{References}

[1] K. Rohde, "Ecology and biogeography of marine parasites," Adv Mar Biol, vol. 43, pp.1-86, 2002.

[2] L. Margolis and J.R. Arthur, "Synopsis of the parasites of fishes of Canada," Bull Fish Res Bd Can, vol. 199, pp.1-269, 1979.

[3] T.E. McDonald and L. Margolis, "Synopsis of the parasites of fishes of Canada: Supplement (1978-1993)," Can Spec Publ Fish Aquat Sci, vol. 122, pp.1-265, 1995.

[4] H.W. Palm, "Ecology of Pseudoterranova decipiens (Krabbe, 1878) (Nematoda: Anisakidae) from Antarctic waters," Parasitol Res, vol. 85, pp.638-646, 1999.

[5] S. Klimpel, A. Seehagen, H.W. Palm, H. Rosenthal, "Deep-water metazoan fish parasites of the world," Logos Verlag, Berlin, 2001.

[6] S. Klimpel, M.W, Busch, E. Kellermanns, S. Kleinertz, H.W. Palm, "Metazoan deep-sea fish parasites," Acta Biologica Benrodis, Suppl. 11, Verlag Natur \& Wissenschaft, Solingen, 2009.

[7] H.W Palm and S. Ruckert, "A new approach to visualize ecosystem health by using parasites," Parasitol Res, vol. 105, pp.539-553, 2009.

[8] P. Galli, G. Crosa, L. Mariniello, M. Ortis, S. D’Amelio, "Water quality as a determinant of the composition of fish parasite communities," Hydrobiologia, vol. 452, pp.173-179, 2001.
[9] K. MacKenzie, H.H. Williams, B. Williams, A.H. McVicar, R.I. Siddall, "Parasites as indicators of water quality and the potential use of helminth transmission in marine pollution studies," Adv Parasitol 35, pp.86-245, 1995.

[10] J.H. Landsberg, B.A. Blakesley, R.O. Reese, G. McRae, P.R. Forstchen, "Parasites of fish as indicators of environmental stress," Env Monit Assess, vol. 51, pp.211-232, 1998.

[11] R.A. Khan, J. Thulin, "Influence of pollution on parasites of aquatic animals," Adv Parasit, vol. 30, pp.201-239, 1991.

[12] W.E. Yeomans, J.C. Chubb, R.A. Sweeting, "Use of protozoan communities for pollution monitoring," Parassitologia, vol.39, pp.201212, 1997.

[13] V.M. Vidal-Martı'nez, D. Pech, B. Sures, S.T. Purucker, R. Poulin, "Can parasites really reveal environmental impact?," Trends Parasitol, vol 26, pp.44-51, 2010.

[14] S. Ruckert, W. Hagen, A.T. Yuniar, H.W. Palm, "Metazoan parasites of fishes and their potential use as biological indicators in the Segara Anakan Lagoon, Indonesia," Reg Environ Change, vol.9, pp.315-328, 2009.

[15] K.D. Lafferty, "Environmental parasitology: what can parasites tell us about human impacts on the environment?," Parasitol Today, vol.13, pp.251-255, 1997.

[16] D.J. Marcogliese and D.K. Cone, "Parasite communities as indicators of ecosystem stress," Parassitologia, vol.39, pp.227-232, 1997.

[17] R.M. Overstreet, "Parasitological data as monitors of environmental health," Parassitologia, vo.39, pp.169-175, 1997.

[18] H.H. Williams and K. MacKenzie, "Marine parasites as pollution indicators: an update," Parasitology, vol126, pp27-41, 2003.

[19] D.J Marcogliese, "Parasites of the superorganism: Are they indicators of ecosystem health?," Int J Parasitol, vol.35, pp.705-716, 2005.

[20] A.O. Bush, K.D. Lafferty, J.M. Lotz, A.W. Shostak," Parasitology meets ecology on its own terms: Margolis et al. Revisited," J Parasitol, vol.83(4), pp.575-583, 1997.

[21] R.H. Skinner, "The interrelation of water quality, gill parasites, and gill pathology of some fishes from South Biscayne Bay, Florida," Fisher Bull, vol.80, pp.269-280, 1982.

[22] K. MacKenzie, "Parasites as pollution indicators in marine ecosystems: a proposed early warning system," Mar Poll Bull, vol.38, pp.955-959, 1999.

[23] C. Jennerjahn, I. Jänen, C. Propp, S. Adi, S.P. Nugroho, "Environmental impact of mud volcano inputs on the anthropogenically altered Porong River and Madura Strait coastal waters, Java, Indonesia. Estuarine," Coastal and Shelf Science vol.130, pp.152-160, 2013.

[24] B. Kahn, "Komodo National Park Cetacean Survey," TNC, APEX Environment, 2001.

[25] P. Soede, "The Solor and Alor Islands Expedition Results," TNC, WWF, David And Lucille Packard Foundation, 2002.

[26] M. Yunus, "The cause of Pilot Whale (Globicephala macrorhynchus) stranded on Probolinggo Coastal," unpublished.

[27] H. Moller, "Pollution and parasitism in the aquatic environment," Int J Parasitol, vol.17, pp.353-361, 1987. 